Egyptian Journal of Aquatic Biology \& Fisheries

Zoology Department, Faculty of Science,

Ain Shams University, Cairo, Egypt.

ISSN $1110-6131$

Vol. 24(7): 307 - 317 (2020)

www.ejabf.journals.ekb.eg

\title{
Quality attributes of artificial dried and dried salted Sand smelt fish
}

\section{(Atherina boyeri)}

\author{
Abdelrahman S. Abou-Zied, Abdelrahman S. Talab*, Mohamed A. Ibrahim and \\ Sayed M. Ibrahim \\ Fish Processing and Technology Laboratory, Fisheries Division, \\ National Institute of Oceanography and Fisheries (NIOF), Cairo, Egypt. \\ *Corresponding Author: Abdelrahman_saidh@yahoo.com
}

\section{ARTICLE INFO \\ Article History: \\ Online: Oct. 25, 2020 \\ Keywords: \\ Fish, \\ Dried salted fish, \\ Atherina boyeri, \\ Quality indices.}

Received: Sept. 23, 2020

Accepted: Oct. 24, 2020

\begin{abstract}
Some quality indices of dried and dried salted Sand smelt fish (Atherina boyeri)were investigated. Fish samples were purchased from El-Anfoshy landing; Alexandria during November 2019. The average length and weight were $6.75 \pm 0.60 \mathrm{~cm}$ and $2.06 \pm 0.49 \mathrm{~g}$, respectively. Cleaned fish samples were divided into three portions; raw, dried (without salting) and dried salted (brined in $13 \%(\mathrm{w} / \mathrm{v})$, for 5, 10 and $15 \mathrm{~min}$ ) and then artificially dried at $50^{\circ} \mathrm{C}$ for $6 \mathrm{hrs}$. Results showed that dried fish sample contained $12.08 \%$ moisture, $3.74 \% \mathrm{NaCl}, \quad 0.61 \mathrm{a}_{\mathrm{w}}$ and $0.28 \%$ acid insoluble ash. The corresponding values of dried salted samples were ranged of 10.68-10.85\%, $7.37-11.00 \%, 0.57-0.59$ and $45-51 \%$, respectively based on salting time. Besides, total viable count and halophilic were 4.18 and $5.61 \log _{10} \mathrm{cfu} / \mathrm{g}$ of the dried sample while they ranged 5.04-5.26 and 5.44-6.40 $\log _{10} \mathrm{cfu} / \mathrm{g}$ of dried salted samples, respectively. However, dried salted fish have got high scores of odour, texture, taste compared with dried fish whereas; there are not significant differences $(P<0.05)$ in appearance and colour tests. In conclusion, artificial drying and salting processes affected markedly in values of quality indices compared with a raw fish sample. However, quality attributes of dried and dried salted Sand smelt were lower than the recommended limits as set by the International Standard Specifications.
\end{abstract}

\section{INTRODUCTION}

Fresh fish contains up to $80 \%$ water and is a highly perishable material. If fresh fish is not directly consumed or processed into finished products; it will quickly decay and become waste. The commonest fish preservation method in Indonesia are salting followed by drying (Bala and Mondol, 2001; Sidhi et al., 2018). Sand smelt (Atherina boyeri) is one of the most abundant species in Mediterranean estuaries and lagoons, so it has a commercial value (Leonardos and Sinis, 2000; Maci and Basset, 2010). The goals of fish drying are economic considerations, environmental concerns and product quality aspects (Okos et al., 1992), increase shelf life, ease of handling and transportation, improve of sensory characteristics (Sawhney, 2005). In addition, dried 
fish is a staple food and is a good source of quality protein (Bellagha et al., 2007). There are different drying methods used to process and preserve shrimp such as; super-heated air drying (Prachayawarakorn et al., 2002), freeze-drying (Lourdes et al., 2007), jetemitted bed drying and hot air drying (Niamnuy et al., 2007), heat pump drying (Zhang et al., 2008), solar drying (Akonor et al., 2016) and it can be done by open-air sun drying, firewood/fuel drying, electrical drying and solar drying (Tiwari et al., 2016). Moreover, AL-Fadhly (2009) reported that using industrial solar dryer gave better results than natural solar dryer, whereas the natural solar drying method requires a large area and long drying time, this is not exploited economically and on a large scale (Immaculate $\boldsymbol{e t}$ al., 2012 and Darvishi et al., 2013). AL-Temimi (2018) found that the microwave drying method gave a high efficiency in drying and eliminating most of the microorganisms. However, some of drying methods have negative effects on the quality attributes (Ajifolokun, 2019). Therefore, this work was planned to evaluate the quality of dried and dried salted Sand smelt fish purchased from daily catch of the Mediterranean Sea at El-Anfoshy landing, Alexandria in November, 2019.

\section{MATERIALS AND METHODS}

Fresh Sand smelt (Atherina boyeri) samples (Fig.1) were purchased from daily catch at El-Anfoshy Landing, Alexandria during November, 2019. Then, they were directly transported using ice box to the Fish Processing and Technology Lab., National Institute of Oceanography and fisheries (NIOF), Alex. Branch, Egypt. The average length and weight of samples were $6.75 \pm 0.60 \mathrm{~cm}$ and $2.06 \pm 0.49 \mathrm{~g}$, respectively.

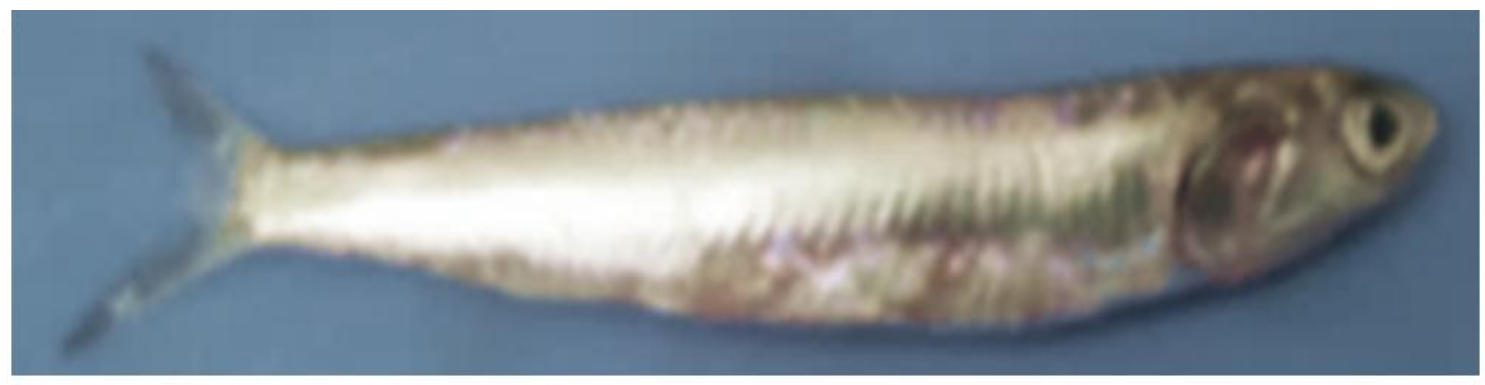

Fig. (1). Raw Sand smelt (Atherina boyeri).

Sodium chloride; Bono salt composed $98.5 \%$ min. sodium chloride, 30-70 ppm potassium iodate and $0.3 \%$ max humidity. It produced by the Egyptian salts \& minerals Company (EMISAL) was used.

Technological processes; the whole fresh fish were washed with clean sea water to remove any impurities and drained. Then cleaned whole fish samples were divided into 5 portions; the first one (control) was stored as it is at $-20^{\circ} \mathrm{C}$ until analysis, the second portion was unsalted, in addition to the third, fourth and fifth portions were salted using brine $13 \%(\mathrm{w} / \mathrm{v})$ for 5,10 and 15 ( $\mathrm{min}$ ), respectively under room temperature.

Drying process; the whole salted fish were quickly washed to remove excess salt and drained again for about $5 \mathrm{~min}$, in addition to unsalted sample were dried at $50^{\circ} \mathrm{C}$ for 6 hrs. in an air drying oven. The dried (unsalted) and dried salted fish were left inside the dryer till cooled, packed in clear polyethylene bag and analyzed. 


\section{Analytical methods}

Chemical composition; moisture, crude protein (total $\mathrm{N} \times 6.25$ ), lipid and ash content of raw, dried and dried salted samples (AOAC, 2005), total carbohydrates content (Maclean et al., 2003), salt content as \% $\mathrm{NaCl}$ (Mol $\boldsymbol{e t}$ al., 2010) and acid insoluble ash content (Codex, 2003) were determined. Water activity (Aw) (Mol $\boldsymbol{e t}$ al., 2010) using Novasina water activity meter, labstart - $\mathrm{a}_{\mathrm{w}}$, Switzerland and $\mathrm{pH}$ value (Zaika et al. (1976)) using pH-meter type Orion Research digital Lonalyzer 1501 wre measured. Total volatile basic nitrogen (TVB-N) and trimethylamine content (AMC, 1979), and 2-Thiobarbituric acid value (Tarladgis $\boldsymbol{e t}$ al., 1960) were determined. Total plate count (TPC) and halophilic bacterial count (HBC) were examined (Oxoid, 1982). Sensory evaluation; dried and dried salted Sand smelt samples were evaluated (Huss, 1995) by ten panelists chosen from the staff members NIOF, Alex., Egypt. The panelists were asked for scoring the quality attributes, appearance, color, taste, odor, texture (mouth-feel) and overall acceptability of by giving scores ranged between 0 to 10 according to the scheme 10 ideal; 9 excellent; 8 very good; 7 good; 6 fairly good; 5 acceptable; 4 fair; 3 poorly fair; 2 poor; 1 very poor and 0 repulsive. The obtained results were statistical analyzed by analysis of variance (One-way ANOVA) using a significance level of $P<0.05$ the SPSS 16 computer program (SPSS).

\section{RESULTS}

\section{Raw Sand smelt fish}

The proximate analysis and quality indices of fresh Sand smelt muscles (flesh) are shown in Table (1). Fresh Sand smelt flesh composed 75.26 $\pm 0.39 \%$ moisture, $17.47 \pm 0.54 \%$ crude protein, $4.32 \pm 0.44 \%$ lipid, $2.53 \pm 0.15 \%$ ash, $1.14 \pm 0.08 \% \mathrm{NaCl}$ and $0.43 \pm 0.35 \%$ carbohydrate content (wet wt.). Concerning quality attributes, the values of physico-chemical quality attributes of Sand smelt flesh were $\mathrm{pH} 6.58 \pm 00.17$, TVBN $14.27 \pm 1.16 \mathrm{mg} \backslash 100 \mathrm{gm}, \mathrm{TMA} 3.51 \pm 0.50 \mathrm{mg} \backslash 100 \mathrm{gm}$ and TBA $0.63 \pm 00.01 \mathrm{mg}$ MDA $\backslash \mathrm{kg}$ sample. Concerning the microbial quality of raw fish samples, the counts of total plate and halophilic bacteria were 4.68 and $4.18 \log _{10} \mathrm{cfu} / \mathrm{g}$, respectively.

Table (1). Proximate analysis (mean \pm SD) and quality indices of raw Sand smelt fish.

\begin{tabular}{|l|c|c|c|}
\hline Constituent & $\%$ & Quality indices & Value \\
\hline Moisture & $75.26 \pm 0.39$ & $\mathrm{pH}$ value & $6.58 \pm 00.17$ \\
\hline Protein & $17.47 \pm 0.54$ & ${ }^{1} \mathrm{TVB}(\mathrm{mg} \backslash 100 \mathrm{~g})$ & $14.27 \pm 1.16$ \\
\hline Lipid & $4.32 \pm 0.44$ & ${ }^{2} \mathrm{TMA}(\mathrm{mg} \backslash 100 \mathrm{~g})$ & $3.51 \pm 0.50$ \\
\hline $\mathrm{Ash}$ & $2.53 \pm 0.15$ & ${ }^{3} \mathrm{TBA}(\mathrm{mg} \backslash \mathrm{kg})$ & $0.63 \pm 00.01$ \\
\hline $\mathrm{NaCl}$ & $1.14 \pm 0.08$ & ${ }^{4} \mathrm{TPC}\left(\log _{10} \mathrm{cfu} / \mathrm{g}\right)$ & 4.68 \\
\hline Carbohydrate & $0.43 \pm 0.35$ & ${ }^{5} \mathrm{HBC}\left(\log _{10} \mathrm{cfu} / \mathrm{g}\right)$ & 4.18 \\
\hline
\end{tabular}




\section{Dried and dried salted fish}

Table (2) shows the proximate composition of dried and dried salted whole Sand smelt fish. Values of chemical composition of dried whole Sand smelt were $12.08 \pm 0.35 \%$ moisture, $66.39 \pm 0.23 \%$ crude protein, $10.87 \pm 0.74 \%$ lipid, $8.38 \pm 0.375$ ash, $3.74 \pm 0.33 \%$ $\mathrm{NaCl}$ and $2.28 \pm 0.21 \%$ carbohydrate content. Concerning dried salted whole fish, the corresponding values of dried salted fish were changed to record $10.68 \pm 0.03 \%$, $57.15 \pm .04 \%, 13.82 \pm 0.11 \%, 16.47 \pm 0.13 \%, 7.37 \pm 0.17 \%$ and $1.88 \pm 0.25 \%$, respectively of samples salted for $5 \mathrm{~min}, 10.85 \pm 0.18 \%, 58.20 \pm 0.23 \%, 11.69 \pm 0.25 \%, 17.08 \pm 0.01 \%$, $8.31 \pm 0.16 \%$ and $2.19 \pm 0.68 \%$, respectively of samples salted for $10 \mathrm{~min}$, and $10.71 \pm 0.01 \%, 56.61 \pm 0.38 \%, 11.51 \pm .06 \%, 18.94 \pm 0.38 \% .11 .00 \pm 0.17 \%$ and $2.21 \pm .03 \%$, respectively of samples salted for $15 \mathrm{~min}$.

Table (2). Proximate analysis (mean \pm SD) of dried and dried salted Sand smelt fish.

\begin{tabular}{|l|c|c|c|c|}
\hline \multirow{2}{*}{$\begin{array}{c}\text { Constituent } \\
(\%)\end{array}$} & \multirow{2}{*}{${ }^{*}$ Dried fish } & \multicolumn{3}{c|}{ Dried salted fish treatments; } \\
\cline { 3 - 5 } & & $5 \mathrm{~min}$ & $10 \mathrm{~min}$ & $15 \mathrm{~min}$ \\
\hline Moisture & $12.08 \pm 0.25^{\mathrm{a}}$ & $10.68 \pm 0.02^{\mathrm{b}}$ & $10.85 \pm 0.13^{\mathrm{b}}$ & $10.71 \pm 0.01^{\mathrm{b}}$ \\
\hline Protein & $66.39 \pm 0.16^{\mathrm{a}}$ & $57.15 \pm .03^{\mathrm{c}}$ & $58.20 \pm 0.17^{\mathrm{b}}$ & $56.61 \pm 0.38^{\mathrm{d}}$ \\
\hline Lipid & $10.87 \pm 0.52^{\mathrm{c}}$ & $13.82 \pm 0.08^{\mathrm{a}}$ & $11.69 \pm 0.18^{\mathrm{b}}$ & $11.51 \pm .05^{\mathrm{b}}$ \\
\hline Ash & $8.38 \pm 0.26^{\mathrm{d}}$ & $16.47 \pm 0.09^{\mathrm{c}}$ & $17.08 \pm 0.01^{\mathrm{b}}$ & $18.94 \pm 0.38^{\mathrm{a}}$ \\
\hline $\mathrm{NaCl}$ & $3.74 \pm 0.33^{\mathrm{d}}$ & $7.37 \pm 0.17^{\mathrm{c}}$ & $8.31 \pm 0.16^{\mathrm{b}}$ & $11.0 \pm 0.17^{\mathrm{a}}$ \\
\hline Carbohydrate & $2.28 \pm 0.15^{\mathrm{a}}$ & $1.88 \pm 0.18^{\mathrm{a}}$ & $2.19 \pm 0.48^{\mathrm{a}}$ & $2.21 \pm .28^{\mathrm{a}}$ \\
\hline
\end{tabular}

${ }^{*}$ Dried fish: unsalted fish; Letters in same row represent significant difference $(p<0.05)$

\section{Quality attributes of dried and dried salted fish}

Physico-chemical quality attributes of dried and dried salted whole Sand smelt fish are presented in Table (3). Dried fish samples have $\mathrm{pH} 6.66 \pm 0.11, \mathrm{a}_{\mathrm{w}} 0.61 \pm 0.01$, acid insoluble ash $0.28 \pm 0.02 \%$, TVB $74.99 \pm 0.18 \mathrm{mg} \backslash 100 \mathrm{~g}$, TMA $5.06 \pm 0.23 \mathrm{mg} \backslash 100 \mathrm{~g}$, and TBA $1.12 \pm 0.03 \mathrm{mg}$ MDAlkg sample. With regard to the dried salted fish, the values of treatments; 5, 10 and $15 \mathrm{~min}$ were $6.69 \pm 0.14,6.51 \pm 0.17$ and $6.75 \pm 0.01$ of $\mathrm{pH}, 0.59 \pm 0.01$, $0.59 \pm 0.02$ and $0.57 \pm 0.02$ of $\mathrm{a}_{\mathrm{w}}, 0.45 \pm 0.16,0.46 \pm 0.05$ and $0.51 \pm 0.05 \%$ of acid insoluble ash, 77.41 $\pm 0.86,83.49 \pm 1.65$ and $89.02 \pm 1.70 \mathrm{mg} \backslash 100 \mathrm{~g}$ of TVB, 5.79 $\pm 0.27,6.42 \pm 0.26$ and $7.46 \pm 0.15 \mathrm{mg} \backslash 100 \mathrm{~g}$ of TMA and $2.07 \pm 0.08,2.25 \pm 0.012 .28 \pm 0.01 \mathrm{mg}$ MDAlkg, respectively.

Table (3). Quality indices (mean \pm SD) of dried and dried salted Sand smelt fish.

\begin{tabular}{|c|c|c|c|c|}
\hline \multirow{2}{*}{ Index } & \multirow[b]{2}{*}{ "Dried fish } & \multicolumn{3}{|c|}{ Dried salted fish treatments; } \\
\hline & & $5 \mathrm{~min}$ & $10 \mathrm{~min}$ & $15 \mathrm{~min}$ \\
\hline $\mathrm{pH}$ value & $6.66 \pm 0.11^{\mathrm{a}}$ & $6.69 \pm 0.14^{\mathrm{a}}$ & $6.51 \pm 0.17^{\mathrm{a}}$ & $6.75 \pm 0.01^{\mathrm{a}}$ \\
\hline Water activity $\left(\mathrm{a}_{\mathrm{w}}\right)$ & $0.61 \pm 0.01^{\mathrm{a}}$ & $0.59 \pm 0.01^{\mathrm{a}}$ & $0.59 \pm 0.02^{\mathrm{a}}$ & $0.57 \pm 0.02^{\mathrm{a}}$ \\
\hline Acid insoluble ash (\%) & $0.28 \pm 0.02$ & $0.45 \pm 0.16$ & $0.46 \pm 0.05$ & $0.51 \pm 0.05$ \\
\hline${ }^{1} \mathrm{TVB}(\mathrm{mg} \backslash 100 \mathrm{~g})$ & $74.99 \pm 0.18^{\mathrm{c}}$ & $77.41 \pm 0.86^{\mathrm{c}}$ & $83.49 \pm 1.65^{b}$ & $89.02 \pm 1.70^{\mathrm{a}}$ \\
\hline${ }^{2}$ TMA (mg\100g) & $5.06 \pm 0.23^{\mathrm{c}}$ & $5.79 \pm 0.27^{b}$ & $6.42 \pm 0.26^{b}$ & $7.46 \pm 0.15^{\mathrm{a}}$ \\
\hline${ }^{3} \mathrm{TBA}(\mathrm{mglkg})$ & $1.12 \pm 0.03^{\mathrm{c}}$ & $2.07 \pm 0.08^{b}$ & $2.25 \pm 0.01^{\mathrm{a}}$ & $2.28 \pm 0.01^{\mathrm{a}}$ \\
\hline
\end{tabular}

*Dried fish: unsalted fish; ${ }^{1}$ TVB: total volatile bases; ${ }^{2}$ TMA: trimethylamine; ${ }^{3}$ TBA: thiobarbituric acid. Letters in same row represent significant difference $(p<0.05)$. 


\section{Microbial examination}

The microbial aspects of dried and dried salted fish samples are shown in Fig. (2). TVC was $5.61 \log _{10} \mathrm{cfu} / \mathrm{g}$ of dried fish sample while it recorded 5.04 and $5.26 \log _{10} \mathrm{cfu} / \mathrm{g}$ of dried salted fish samples soaked for 5, 10 and $15 \mathrm{~min}$, respectively. On the other side, $\mathrm{HBC}$ was $4.18 \log _{10} \mathrm{cfu} / \mathrm{g}$ of dried fish sample and it reached to 5.60, 5.44 and $6.40 \log _{10}$ $\mathrm{cfu} / \mathrm{g}$ of dried salted fish samples soaked for 5, 10 and 15min, respectively.

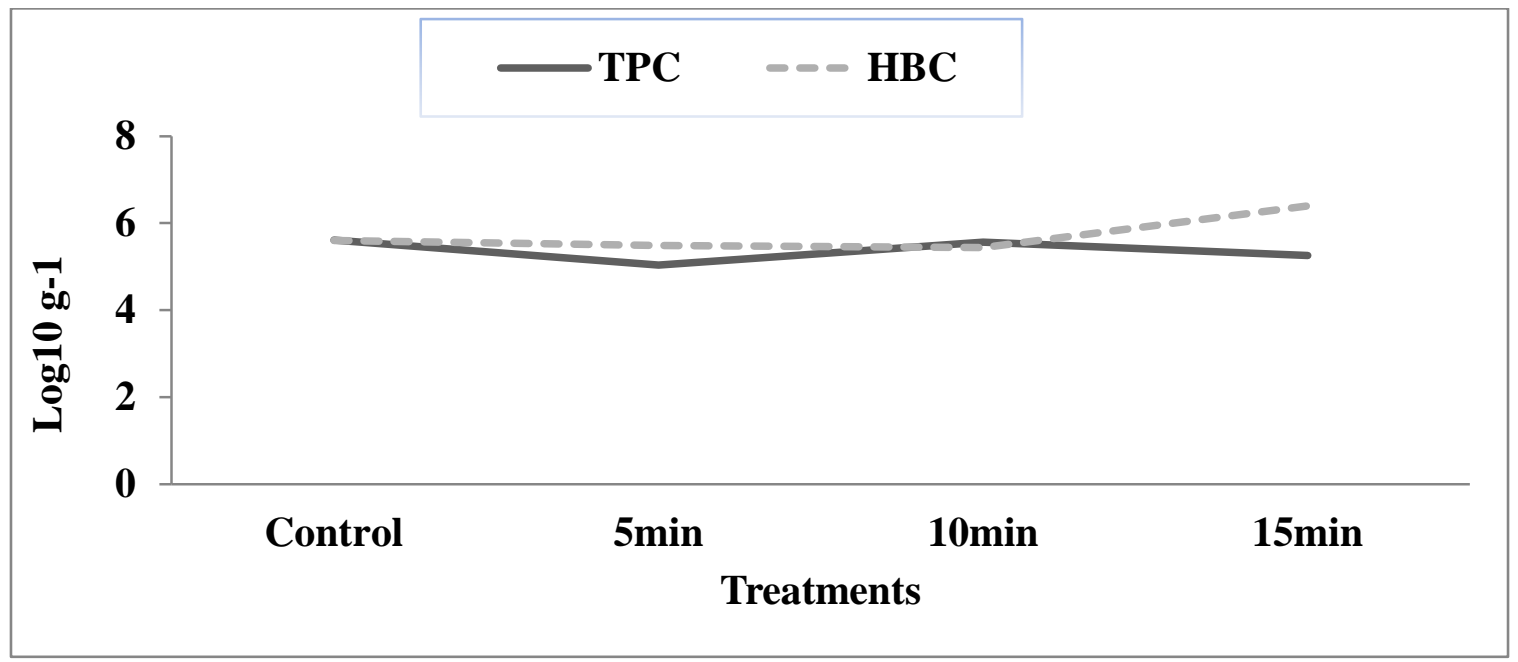

Fig. (2). Microbial aspects $\left(\log _{10} \mathrm{cfu} \mathrm{g}^{-1}\right)$ of dried (control) and salted dried Sand smelt fish.

${ }^{1}$ TPC: total plate count; ${ }^{2} \mathrm{HBC}$ : halophilic bacteria count.

\section{Sensorial quality}

Sensory properties of dried and dried salted Sand smelt fish are exhibited in Table (4). A high score $(7.7 \pm 0.67)$ of appearance property was given by panelists to dried salted treatment $10 \mathrm{~min}$, followed by treatments 5 and $10 \mathrm{~min}(7.5 \pm 0.85)$ and dried sample (7.4 \pm 0.84$)$. Colour test, the highest score $(7.7 \pm 0.82)$ was given to dried sample than other ones and the lowest score of colour $(7.3 \pm 0.67)$ was given to treatment 15 min than other treatments. Treatment 5 has got a high score in texture property compared to others. The highest scores $(7.9 \pm 0.52)$ of odour and taste properties were given to treatment $10 \mathrm{~min}$ compared to others. The best score $(8.0 \pm 0.47)$ of overall acceptability was given to treatment $10 \mathrm{~min}$.

Table (4). Sensory properties of dried and dried salted Sand smelt fish.

\begin{tabular}{|l|c|c|c|c|}
\hline \multirow{2}{*}{ Property } & \multirow{2}{*}{$*$ Dried fish } & \multicolumn{3}{|c|}{ Dried salted fish treatments; } \\
\cline { 3 - 5 } & ${ }^{*}$ 5 min & $\mathbf{1 0}$ min & $\mathbf{1 5}$ min \\
\hline Appearance & $7.4 \pm 0.84^{\mathrm{a}}$ & $7.5 \pm 0.85^{\mathrm{a}}$ & $7.7 \pm 0.67^{\mathrm{a}}$ & $7.5 \pm 0.85^{\mathrm{a}}$ \\
\hline Colour & $7.7 \pm 0.82^{\mathrm{a}}$ & $7.6 \pm 0.97^{\mathrm{a}}$ & $7.6 \pm 0.97^{\mathrm{a}}$ & $7.3 \pm 0.67^{\mathrm{a}}$ \\
\hline Odour & $6.4 \pm 0.69^{\mathrm{b}}$ & $7.5 \pm 0.71^{\mathrm{a}}$ & $7.9 \pm 0.52^{\mathrm{a}}$ & $7.7 \pm 0.67^{\mathrm{a}}$ \\
\hline Taste & $6.4 \pm 0.52^{\mathrm{c}}$ & $7.4 \pm 0.96^{\mathrm{ab}}$ & $7.9 \pm 0.99^{\mathrm{a}}$ & $6.9 \pm 0.58^{\mathrm{bc}}$ \\
\hline Texture & $7.2 \pm 0.63^{\mathrm{c}}$ & $8.1 \pm 0.99^{\mathrm{a}}$ & $7.8 \pm 0.79^{\mathrm{ab}}$ & $7.8 \pm 0.79^{\mathrm{ab}}$ \\
\hline Overall acceptability & $6.4 \pm 0.52^{\mathrm{c}}$ & $7.2 \pm 0.42^{\mathrm{b}}$ & $8.0 \pm 0.47^{\mathrm{a}}$ & $7.0 \pm 0.47^{\mathrm{b}}$ \\
\hline
\end{tabular}

*Dried fish: unsalted fish; Letters in same row represent significant difference $(p<0.05)$. 


\section{Crucial quality and safety parameters}

Table (5) shows the crucial quality and safety parameters for dried and dried salted fish products. Values of moisture, water activity, sodium chloride, acid insoluble ash content were lower than the recommended values as set by the international standard specifications.

Table (5). Comparison between the present study and the international standard specifications.

\begin{tabular}{|c|c|c|c|c|c|c|c|c|}
\hline \multirow[b]{3}{*}{ References } & \multicolumn{8}{|c|}{ Standard Specifications of dried and dried salted fish; } \\
\hline & \multicolumn{4}{|c|}{ Dried fish } & \multicolumn{4}{|c|}{ Dried salted fish } \\
\hline & Moisture \% & $\mathbf{a}_{\mathbf{w}}$ & $\underset{\%}{\mathrm{NaCl}}$ & $\begin{array}{c}\text { Acid } \\
\text { insoluble } \\
\text { ash } \%\end{array}$ & $\begin{array}{c}\text { Moisture } \\
\%\end{array}$ & $\mathbf{a}_{\mathbf{w}}$ & $\underset{\%}{\mathrm{NaCl}}$ & $\begin{array}{c}\text { Acid } \\
\text { insoluble } \\
\text { ash } \%\end{array}$ \\
\hline The present study & 12.08 & 0.61 & 3.74 & 0.28 & $\begin{array}{c}10.68- \\
10.85\end{array}$ & $\begin{array}{c}0.57- \\
0.59\end{array}$ & $\begin{array}{l}7.34- \\
11.00\end{array}$ & $45-51$ \\
\hline Codex Stan .189 - 1993 & $\begin{array}{l}\text { Not more } \\
\text { than } 18 \%\end{array}$ & - & - & - & - & - & - & - \\
\hline $\begin{array}{ll}\text { CODEX } & \text { STAN 236- } \\
2003, & \text { Amendment, } \\
2013 & \end{array}$ & - & 0.75 & - & 1.5 & - & 0.75 & - & 1.5 \\
\hline Indian Std., 2001 & $8-20$ & - & $\begin{array}{c}2.5- \\
7.5\end{array}$ & $1.0-1.5$ & $30-40$ & & $10-30$ & 1.5 \\
\hline Philippines Std., 2015 & $\begin{array}{l}\text { Not more } \\
\text { than } 40 \%\end{array}$ & 0.70 & $\begin{array}{c}15 \\
(\mathrm{DW})\end{array}$ & 1.5 & $\begin{array}{l}\text { Not more } \\
\text { than } 40 \%\end{array}$ & 0.70 & $\begin{array}{c}15 \\
(\mathrm{DW})\end{array}$ & 1.5 \\
\hline
\end{tabular}

$-:$ not found.

\section{DISCUSSION}

In this study, the chemical composition of raw Sand smelt fish (Table 1) was disagreement except moisture content (75.26\%) with those findings by Ibrahim et al. (2019); they found that the proximate composition of raw Sand smelt (wet wt.) were $75.49 \%, 13.02 \%, 1.83 \%$ and $9.60 \%$ for moisture, crude protein, lipid and ash content, respectively and also, Bilgin $\boldsymbol{e t}$ al. (2011) found that raw Sand smelt flesh contained $78.28 \%$ moisture, $19.64 \%$ protein, $1.84 \%$ lipid and $1.67 \%$ ash content. Variation in chemical composition of fish is due to environment of catch, age, sex, season of catch, feeding behavior and analyzed portion as reported by several studies (Huss et al., 2004). Concerning quality attributes (Table 1), value of $\mathrm{pH}(6.58 \pm 00.17)$ of fresh Sand smelt sample was lower than 6.7-7.0 (Huss, 1995). Also, the results were disagreement exception TVB $(14.27 \pm 1.16 \mathrm{mg} \backslash 100 \mathrm{gm})$ with those reported by Ibrahim $\boldsymbol{e t}$ al. (2019); raw fish had $6.35 \mathrm{pH}$ and $14.7 \mathrm{mgTVB}-\mathrm{N} / 100 \mathrm{~g}$ sample while the value of TBA was 0.88 $\mathrm{mg} \mathrm{MA} / \mathrm{kg}$ sample.

Concerning dried and dried salted fish, a different significant $(P \leq 0.05)$ in proximate analysis of dried and dried salted Sand smelt samples (Table 2) is due mainly to effect of salting and drying processes (Al-Rubai et al., 2020). Similar trends according to different drying methods were reported by Nooralabettu (2008); Gwabrawy (2013); Farid et al. (2017); AL-Temimi (2018) and Patterson et al. (2018). Quality attributes of dried and dried salted fish products (Table 3), $\mathrm{pH}$ value was lower than the $\mathrm{pH}$ values of dried Mugil cephalus and Harpodon nehereus (Azam et al., 2003) and also than 5.60 of 
industrial solar dried Thalha fish (AL-Fadhly, 2009). Moreover, some results also were partially agreement with those findings by Al-Noor (2008). Values of water activity were in accordance with those reported by Quek et al. (2007) and Aberoumand (2010); all microbial growth is inhibited at water activity below 0.60. Values of acid insoluble ash were lower than the recommended value (1-1.5\%) as set by Indian Std. (2001) and Philippines Std. (2015) and there is a significant different between dried and dried salted treatments. TVB and TMA (Table 3) in dried and dried salted fish samples increased progressively. Similar trend was found by Al-Noor (2008). Also, the results of TVB were higher than those reported by Azam et al. (2003); TVB value of dried Mugil cephalus was $62.23 \mathrm{mg} / 100 \mathrm{~g}$ in winter and decreased to $57.82 \mathrm{mg} / 100 \mathrm{~g}$ in the summer. Values of TBA were accepted increased in dried fish and dried salted fish samples compared to its original value $0.63 \mathrm{mg}$ MDAlkg (Table 1). Values of TBA were within in the range of TBA value (1.81- 6.32 mg MAlkg) for dried fish samples (Al-Shatty, 2006). While they were higher than $0.531,0.382$ and $0.402 \mathrm{mg} \mathrm{MA} / \mathrm{kg}$ fish for dried fish by using vacuum solar dryer, vacuum electric dryer, and natural solar drying, respectively (ALGwabrawy, 2013) and also than $0.71 \mathrm{mg}$ MDA/100g of dried fish (Patterson et al., 2018).

Concerning microbiological quality, TPC of raw fish sample (Table 1) was lower than the upper acceptability limit $\left(7 \log _{10} \mathrm{CFU} / \mathrm{g}\right.$ flesh) for total viable count in fresh fish as recommended by ICMSF (1986). Results of TPC and HBC were higher values than $2.48,2.00 \log _{10} \mathrm{cfu} / \mathrm{g}$, respectively of raw Sand smelt fish (Ibrahim et al., (2019). Data presented in Fig. (2), it was observed that salting then drying caused suppress in TVC and encouraged in growth of HBC. This phenomenon agrees with those findings by Mol $\boldsymbol{e t} \boldsymbol{a l}$. (2010) and Wang et al. (2011). Moreover, the results of microbial counts of dried and dried salted samples were lower than those reported by Ajifolokun (2019); the ovendried shrimp powder at $70^{\circ} \mathrm{C}$ had the lowest total plate count (TPC) of $12 \times 10^{5} \mathrm{cfu} / \mathrm{g}$ (i.e. $\left.6.08 \log _{10} \mathrm{CFU} / \mathrm{g}\right)$ than the sun-dried shrimp powder $\left(36 \times 10^{5} \mathrm{cfu} / \mathrm{g}\right.$ (i.e. $6.56 \log _{10}$ $\mathrm{CFU} / \mathrm{g}$ ).

With regard to sensorial quality (Table 4), dried salted fish samples had high scores than only dried samples. There are significant differences $(P \leq 0.05)$ in texture, odour, taste, and overall acceptability between dried and dried salted treatments, and also within dried salted treatments however, appearance and colour properties were not found. The results of sensory evaluation of dried and dried salted fish are based mainly on season of catch (Azam et al., 2003), fish species (AL-Gwabrawy, 2013 and Farid et al., 2017), salting and drying methods (Immaculate et al., 2013; Patterson et al., 2018; Ajifolokun, 2019 and Al-Rubai et al., 2020). From Table (5) our results were lower than the recommended limits (30-40\% moisture, $0.75 \mathrm{a}_{\mathrm{w}}, 1.5 \%$ acid insoluble ash content) as set by Codex (1993 \& 2003); Indian Std. (2001) and Philippines Std. (2015).

\section{CONCLUSION}

Based on the results obtained, biochemical quality of raw Sand smelt fish proved that fish samples had a high degree of freshness. Salting and drying processes and also time of salting caused desirable changes in quality indices of fish products investigated. Also, quality attributes in both dried and dried salted fish products were lower than the recommended limits of international standard specifications. 


\section{REFERENCES}

Aberoumand, A. (2010). The effect of water activity on preservation quality of fish, a Review Article. World Journal of Fish and Marine Sciences, 2: 221-225.

Ajifolokun, O. M.; Basson, A. K.; Osunsanmi, F.O. and Zharare, G.E. (2019). Effects of drying methods on quality attributes of shrimps. J. Food Process Technol, 10 (1): 1- 5.

Akonor, P.T; Ofori, H.; Dziedzoave, N.T. and Kortei, N.K. (2016). Drying characteristics and physical and nutritional properties of shrimp meat as affected by different traditional drying techniques. Int. J. Food Sci., Volume 2016, Article ID 7879097, 5 pages. http://dx.doi.org/ 10.1155/2016/7879097.

Al-Fadhly, N.K.Z. (2009). Salting and drying of the Thelah fish Scomberoides commersonianus and studying its quality characteristics using sensory, chemical, physical and microbial indices. M. Sc. Thesis, Coll. Agric., Univ. Basrah. 195pp. (In Arabic).

Al-Gwabrawy, A.A. (2013). Design and manufacturing of a vacuum solar dryer and study it's efficiency in fish drying microbiological, chemical and sensory. Dissertation, Agriculture Collage, University of Basrah.

Al-Noor, J.M.I. (2008). Comparing the effect of solar drying and industrial drying on some chemical and microbial Properties and quality of two types of marine fish, Hamour (Epinephelus coioidis) and Sharee (Lethrinus nebulosue). Dissertation, College of Agriculture, University of Basrah.

Al-Rubai,ya, H. H.; Abdul Hassana, K. H. and Eskandder, M. Z. (2020). Drying and salting fish using different methods and their effect on the sensory, chemical and microbial indices. Multidisciplinary Reviews. https://doi.org/10.29327/ multi. 2020003.

Al-Shatty, S.M.H. (2006). Technological, chemical and microbial study on smoking, pickling and drying of four species of marine fish common in Basrah. Thesis, Agriculture Collage, University of Basrah.

Al-Temimi, W.K.A. (2018). Studying of physical and chemical properties and microbial content for dried fish by microwave. Diyala Journal of Agricultural Sciences 10:12-28.

AMC (1979). Analytical Methods Committee. Recommended method for the examination of fish and fish products. Analyst, 104: 434-439.

AOAC (2005). Association of Official Analytical Chemists. Official methods of analysis of AOAC international (18 ${ }^{\text {th }}$ edition). Horwitz, W., Latimer, G.W. Jr. (eds.). USA, $3000 \mathrm{p}$

Azam, K.; Basher, M.Z.; Ali, M.Y.; Asaduzzaman, M. and Hossain, M.M. (2003). Comparative study of organoleptic, microbiological and biochemical qualities of four selected dried fish in summer and winter. Pakistan Journal of Biological Sciences 6:2030-2033. 
Bala, B. K. and Mondol, M. R. A. (2001). Experimental investigation on solar drying of fish using solar tunnel dryer. Drying Technology, 19 (2):427-436.

Bellagha, S.; Sahli, A.; Farhat, A.; Kechaou, N. and Glenza, A. (2007). Studies on salting and drying of sardine (Sardinella aurita): Experimental kinetics and modeling. Journal of Food Engineering, 78(3):947-952.

Bilgin, S.; Çetinkaya, S. and Bolat, Y. (2011). Changes on the nutritional compositions of the Sand smelt (Atherina Boyeri Risso, 1810) marinade during Storage. African Journal of Biotechnology, 10 (16):3197-3203.

CODEX STAN 189 (1993). Standard for dried shark fins.

CODEX STAN 236 (2003).Codex Standard for Boiled Dried Salted Anchovies. Codex Alimentarius Commission. Food and Agriculture Organization/World Health Organization (FAO/WHO) Joint Programme. Rome, Italy. (www.codexalimentarius.org) Adopted in 2003. Amendment.

Darvishi, H.; Azadbakht, M.; Rezaeiasl, A. and Farhang, A. (2013). Drying characteristics of sardine fish dried with microwave heating. Journal Saudi Soc. Agric. Sci. 12: 121-127.

Farid, F.; Latifa, G. A.; Chakraborty, S.C.; Nahid, M.N. and Begum, M. (2017). Performance and quality assessment of sun-dried salted Channa punctatus (Bloch, 1793 ) and Mystus tengra (Hamilton-Buchanan, 1822) during refrigeration $\left(4^{\circ} \mathrm{C}\right)$ storage. International Journal of Food Science and Nutrition. Vol. 2(1): 157-162 .

Huss, H.H. (1995). Quality and quality changes in fresh fish: FAO Fisheries technical paper No. 348.FAO, Rome.

Huss, H.H.; Ababouch, L. and Gram, L. (2004). Assessment and management of seafood safety and quality. FAO Fisheries Technical Paper, No 444. Rome, FAO.

Ibrahim, S.M.; Mohamed, S.M. and Ibrahim, M. A. (2019). Biochemical changes and economical estimation of salted Sand smelt fish (Atherina boyeri). Egyptian Journal of Aquatic Biology \& Fisheries, Vol. 23(2): 411 - 419.

ICMSF (1986). International Commission on Microbiological Specifications for Food. Sampling plans for fish and shellfish. In: ICMSF, microorganisms in foods: sampling for microbiological analysis. Principles and scientific applications. 2nd ed., vol. 2. Toronto, Buffalo, London: University of Toronto Press; 1986.

Immaculate, J.; Sinduja, P. and Patterson, Jamila (2012). Biochemical and microbial qualities of Sardinella fimbriata sun dried in different methods. J. Internal. Food Res., 19:1699-1703.

Indian Standard (2001). Fish - dried and dry-salted specification. IS14950.

Leonardos, I. and Sinis, A. (2000). Short communication: Age, growth and mortality of Atherina boyeri Risso, 1810 (Pisces: Atherinidae) in the Mesolongi and Etolikon lagoons (W. Greece). Fisheries Research, 45: 81-91. 
Lourdes, M.D.; Fernando, L.G. and Ramon, P. (2007). Comparison of freezing and thawing treatments on muscle properties of white leg shrimp (litopenaeus vannamei). J. Food Biochem., 31: 563-576.

Maci, S. and Basset, A. (2010). Spatio-temporal patterns of abundance, size structure and body condition of Atherina boyeri (Pisces: Atherinidae) in a small non-tidal Mediterranean lagoon. Estuarine, Coastal and Shelf Science, 87: 125-134.

Maclean, W.; Harnly, J.; Chen, J.; Chevassus-Agnes, S.; Gilani, G.; Livesey, G., and Warwick, P. (2003). Food energy- methods of analysis and conversion factors. Food and Agriculture Organization of the United Nations Technical Workshop Report (Vol. 77).

Mol S.; Cosansu, S.; Alakavuk, D. U. and Ozturanm S. (2010). Survival of Salmonella Enteritidis during salting and drying of horse mackerel (Trachurus trachurus) fillets. International Journal of Food Microbiology, 13: 36-40.

Niamnuy, C.; Devahastin, S. and Soponronnarit, S. (2007). Effects of process parameters on quality changes of shrimp during drying in a jet-spouted bed dryer. J. Food Sci. 72: E553-E563.

Nooralabettu, K.P. (2008). Effect of sun drying and artificial drying of fresh, salted Bombay duck (Harpodon neherius) on the physical characteristics of the product. Journal of Aquatic Food Product Technology, 17, 99-116.

Okos, M. R.; Narsimhan, G.; Singh, R. K. and Weitnauer, A. C. (1992). Food dehydration. In: Heldman, D. R. and Lund, D. B. Editors. Handbook of food engineering, Marcel Dekker, New York.

Oxoid (1982). Oxoid manual of culture media, ingredients and other laboratory services. $5^{\text {th }}$ Oxoid limited.

Patterson, Jamila; Kailasam, S.; Giftson, H. and Immaculate, J. K. (2018). Effect of drying technologies on the biochemical properties of Stolephorus commersonnii. Food Quality and Safety, 2018, 3, 153-158.

PHILIPPINE NATIONAL STANDARD (2015). Final draft, Dried Anchovies. BUREAU of Agriculture and fisheries Standards.

Prachayawarakorn, S.; Soponronnarit, S.; Wetchacama, S. and Jaisut, D. (2002). Desorption isotherms and drying characteristics of shrimp in superheated steam and hot air. Dry Technol 20: 669-684.

Quek , S. Y. ; Chok N.K. and Swedlund, P. J. (2007). The physiochemical properties of spray-dried watermelon powders. Chemical Engineering and Processing 46 (5):386-392

Sawhney, A. (2005) Quality measures in food trade: the Indian experience. World Econ. 28: $329-348$.

Sidhi, S.D.P.; Pujianto, A.; Prasetyo, D. and Muhfizar, N.A. (2018). Experimental study of salted fish drying under greenhouse dryer. RJOAS, 5(77): 281-28. 
Tarladgis, B. G.; Watts, B. M.; Younathan, M. T. and Dugan, Jr. L. (1960). A distillation method for the quantitative determination of Malonaldehyde in rancid foods. Journal of Am. Oil Chem. Soc., 37: 44-48.

Tiwari, S.; Tiwari, G.N. and Al-Helal , I.M. (2016). Development and recent trends in greenhouse dryer: A review. Renewable and Sustainable Energy Reviews. Elsevier, 65:1048-1064.

Wang, Y.;Zhang, M. and Mujumdar, A. S. (2011). Convective drying kinetics and physical properties of silver carp (Hypophthalmichthys molitrix) fillets. Journal of Aquatic Food Product Technology, 20, 361-378.

Zaika, L.L.; Zell, T.E.; Smith, Z.L.; Palumbo, S.A. and Kissinger, J.C. (1976). The role of nitrite and nitrate in Lebanon Bologna, a fermented sausage. J. Food. Sci., 41: 1457-1460. https://doi. org/10.1111/ j. 1365-2621.1976.tb01195.x

Zhang, G.; Arason, S. and Arnason, S.V. (2008). Physical and sensory properties of heat pump dried shrimp (Pandalus borealis). Trans Chin. Soc. Agric. Eng., 24: 235-239. 